\title{
ALEKSANDER SOtŻENICYN
}

Tekst został przetłumaczony na podstawie: А. Солженицын, Речь в Международной Академии Философии, [w:] tenże, Публицистика. В трех томах, t.1, Верхне-Воложское книжное издательство, Ярославль 1995, s. 599-612. Serdecznie dziękujemy pani Natalii Sołżenicyn za zgodę na publikację tłumaczenia.

\section{Przemówienie w Międzynarodowej Akademii Filozofii (Księstwo Liechtenstein)}

\section{4 września 1993 r.}

\section{Wasze Książęce Mości! Wasza Magnificencjo! Panie i Panowie!}

$\mathbf{Z}$ a każdym razem kiedy przybywam do Księstwa Lichtenstein, ze wzruszeniem wspominam znakomitą lekcję odwagi, którą to malutkie państwo i jego dostojny, świętej pamięci książę Franciszek Józef II, udzielili całemu światu w 1945 roku ${ }^{1}$. Mimo zagrożenia ze strony bezlitosnej sowieckiej machiny wojennej, nie zawahali się oni zaopiekować grupą rosyjskich antykomunistów, która szukała schronienia przed stalinowską tyranią.

Publicystyka Aleksandra Sołżenicyna ma swoisty styl, nierzadko trudny do oddania w języku polskim. Konstrukcja wypowiedzi sprawia, że jego teksty są ekspresywne i niejednokrotnie mają charakter moralizatorski. Efekt ten osiągany jest dzięki powtórzeniom, archaizmom, niekonsekwentnym, a czasami nie w pełni logicznym wywodom oraz szeregowi innych, mniej lub bardziej świadomych, zabiegów stylistyczno-narracyjnych. Tłumacz powyższego artykułu zdecydował się na próbę jak najwierniejszego oddania stylu publicystycznych wypowiedzi noblisty. Niejednokrotnie czyni to za cenę uchybień w języku polskim. W tłumaczeniu zachowano niekonsekwentną pisownię kluczowych dla artykułu wyrazów. W oryginale pojawiają się one raz wielką, raz małą literą, np. samoograniczenie, postęp. Bez zmian pozostawiono również podkreślenia znajdujące się w tekście [przyp. tłum.]. 
Przykład jest tym bardziej pouczający, że w owych miesiącach, potężne demokratyczne mocarstwa, które sformułowały Kartę Atlantycką obiecującą wolność wszystkim uciśnionym, przypochlebiając się zwycięskiemu Stalinowi, bez słowa sprzeciwu oddały mu w niewolę nie tylko całą Europę Wschodnią, ale również - na własnym terytorium - setki tysięcy obywateli sowieckich. Czyniono to wbrew ich jawnej woli, lekceważąc nawet samobójstwa popełnione przez niektórych z nich. Przemocą, bagnetami pchano ich w kierunku Stalina na rozprawę, na męki w łagrach i na śmierć. Skończyło się na tym, że miliony obywateli radzieckich poległo za wspólne zwycięstwo z Zachodem, samemu nie mając prawa do wolności. (Zadziwiające, że wolna prasa zachodnia przez 25 lat pomagała ukrywać tę zbrodnię, a angielskich i amerykańskich generałów oraz administratorów nikt, ani wtedy ani potem, nie nazwał - tak jak na to zasługiwali - zbrodniarzami wojennymi, tym bardziej nikt nie postawił ich przed sądem.)

\section{Polityka i etyka}

Porównanie wyczynu małego Lichtensteinu i zdrady wielkich mocarstw siłą rzeczy prowadzi nas dalej: do problemu roli moralności w polityce, pytania o jej obecność i poziom w sferze politycznej.

Już w XVI wieku, Erazm z Rotterdamu wiązał politykę z etyką i postulował, żeby stanowiła ona przejaw moralności.

Potem, w Oświeceniu - w okresie od XVII do XVIII wieku - nauczyliśmy się od Johna Locke'a, że bezsensownie jest stosować pojęcie moralności w odniesieniu do państwa i jego urządzeń. Dzięki temu politycy, na przestrzeni historii uchylający się od uciążliwych nakazów moralnych, otrzymali jakby dodatkowe teoretyczne uzasadnienie swego postępowania. Moralne motywy działaczy państwowych już przedtem były słabsze od politycznych, lecz w naszych czasach konsekwencje niemoralnych decyzji są zdecydowanie większe.

Jest rzeczą oczywistą, iż przeniesienie kryteriów moralnych z zachowania poszczególnych ludzi, rodzin i niedużych kręgów na polityków nie może odbyć się w skali $1: 1$, gdyż skala, inercja i zadania państwowych instytucji nie są adekwatne do skali i zadań małych grup społecznych. Jednak państwa kierowane są przez polityków, a politycy są zwykłymi ludźmi i ich działania również odbijają się na zwykłych ludziach. Oprócz tego, fluktuacje działań politycznych często bywają dalekie od bezwzględnej konieczności państwowej. Znaczy to, że wiele spośród nakazów moralnych, które stosujemy wobec pojedynczych ludzi - uczciwość, w odróżnieniu od podłości i oszustwa; wielkoduszność i dobro, w miejsce chciwości i nikczemności - 
w znacznej mierze powinno być stosowane w polityce państw, rządów, parlamentów i partii.

Jeśli polityka państwowa, partyjna i społeczna nie opiera się na moralności, to ludzkość nie ma przed sobą żadnej przyszłości. Polityka państwowa i zachowanie człowieka, o ile wynikają z pobudek moralnych, okazują się nie tylko najbardziej ludzkimi, ale - w ostatecznym rozrachunku - najbardziej rokującymi na przyszłość.

Takie wartości jak: idealistycznie wyobrażony cel związany z pojęciem prawdy i życia w prawdzie, przez wieki istnieją w kulturze narodu rosyjskiego. W końcu XIX wieku, rosyjski filozof Włodzimierz Sołowjow utrzymywał, że z chrześcijańskiego punktu widzenia, działanie polityczne jest ściśle związane $\mathrm{z}$ etyką i powinno być zawsze stużbą moralną. Polityka dbająca wyłącznie o interesy nie ma w sobie nic chrześcijańskiego.

Niestety, dziś w mojej ojczyźnie ta zasada została zagubiona jeszcze bardziej niż na Zachodzie. Wygłaszając swoje sądy, jestem świadomy słabości swojej pozycji. Po siedemdziesięciu latach potwornego zniewolenia narodów, w ZSRR pojawiła się nieograniczona wolność. W warunkach ubóstwa skierowała ona wielu na drogę niegodziwości, gdzie powszechny jest brak reguł moralnych. W naszym kraju przez siedemdziesiąt lat niszczono ludzi, lecz nie czyniono tego losowo, jak popadnie. Prześladowano głównie tych, którzy odznaczali się zaletami umysłowymi i moralnymi. Z tego powodu dzisiejsza sytuacja w mojej ojczyźnie przedstawia się o wiele bardziej rozpaczliwie i dziko, niż gdyby była skutkiem działań ludzi mniej zdemoralizowanych, niż ci, którzy do obecnej w Rosji sytuacji doprowadzili.

Nie warto odnosić tych refleksji do oddzielnych krajów i narodów. Pod koniec Drugiego Tysiąclecia chrześcijaństwa stanowią one nasz wspólny problem. Poza tym czy możemy tak lekko rzucać słowo: moralność?

\section{Nakaz Benthama}

Wiek XVIII przyniósł nam nakaz Jeremy'ego Benthama: moralne jest to, co podoba się większości ludzi, człowiek zaś nigdy nie powinien pragnąć niczego ponad to, co sprzyja ochronie jego własnej egzystencji. Cywilizująca się ludzkość podchwyciła tę drogocenną radę! W stosunkach społecznych i ekonomicznych istnieje okrutne wyrachowanie. Stało się ono powszechnie przyjętą normą. Ustąpienie w czymkolwiek oponentowi, konkurentowi uważa się za niewybaczalny błąd. Jeśli jesteś silniejszy i bogatszy - twoja pozycja jest lepsza. Do każdego wydarzenia, czynu, zamiaru przyłożono miarę prawną. Mimo, że ma być ona przeszkodą dla czynów niemoralnych - i często nią 
jest - to jednak czasem, występując w formie „prawniczego realizmu”, ułatwia im drogę.

Należy się cieszyć, że temu wszechobecnemu podejściu sprzeciwia się natura ludzka, która nie pozwala sobie samej zastygnąć w duchowym letargu i zobojętnieć wobec cudzych nieszczęść. Dlatego wielu uczciwych ludzi z Zachodu żywo reaguje na cudze bóle i cierpienia, nie szczędząc pomocy materialnej i innych starań.

\section{Niekończący się Postęp}

Wiedza człowieka, podobnie jak jego umiejętności, nie mogą - i nie powinny - przestać się rozwijać. Począwszy od XVIII wieku rozwój nauki stał się coraz bardziej dynamiczny i zauważalny. Anne Turgot nazwał to zjawisko Progresem i twierdzil, że niechybnie doprowadzi on do powszechnego złagodzenia obyczajów. Podstawą Progresu jest rozwój ekonomiczny. Ta oto dźwięczna nazwa znalazła się w częstym użyciu, stając się niemalże powszechną i dumną filozofią życia: rozwijamy się! Wykształcona ludzkość natychmiast uwierzyła w Postęp. I jakoś nikt nie zapytał: postęp - ale właściwie jaki, czego dotyczacy? Czy w trakcie Postępu nie przyjdzie nam czegoś stracić? Entuzjastycznie spoglądając w przyszłość myślano, iż stanie się on tym czym jeszcze nie jest i obejmie całą ludzkość. To właśnie optymizm dotyczący Postępu sprawił, iż Marks doszedł do wniosku, że historia, nawet bez Boga, doprowadzi do sprawiedliwości.

Upłynęło trochę czasu i okazało się, że Postęp w sposób niezwykły przewyższył oczekiwania. Tyle, że jedynie w sferze technologii (ze szczególnym uwzględnieniem organizacji życia i wynalazków wojennych).

\section{Załamanie Postępu}

Pierwszy fakt, na który dopiero niedawno zwróciliśmy uwagę, zakłada, że niekończący się Postęp nie może mieć miejsca w środowisku ziemskim. Przyroda nie oczekuje byśmy ją ujarzmili, lecz byśmy ją chronili. Tymczasem zjadamy ją (dzięki Bogu, że ten problem, szczególnie w krajach rozwiniętych, został zauważony i rozpoczęły się - chociaż w ilościach niewystarczających działania mające na celu ratowanie środowiska). Jednym z pozytywnych skutków upadku komunizmu był krach najbardziej bzdurnych modeli gospodarczych i najbezmyślniej nieefektywnej ekonomii, stanowiącej pokusę dla wielu krajów.

Okazało się również, że obyczaje, wbrew przewidywaniom, nie uległy złagodzeniu wraz z Postępem. Nie wzięto pod uwagę - tylko i aż - ludzkiej duszy. 
Pozwoliliśmy bezgranicznie rosnąć naszym potrzebom i już sami nie wiemy dokąd nas to zaprowadzi. Wszystko to $\mathrm{z}$ usłużną pomocą firm handlowych, tworzących i wymyślających coraz to nowsze, niejednokrotnie całkiem sztuczne potrzeby, za którymi nieustannie gonimy, ale nie możemy ich zaspokoić. Nigdy nie uda się nam nasycić.

Po co nieustannie gromadzić dobra materialne? Przecież to nigdy nie doprowadzi do nasycenia. (Przenikliwi ludzie już dawno zrozumieli, że własność powinna być podporządkowana innym, wyższym zasadom, powinna posiadać duchowe uzasadnienie i swoją misję. W przeciwnym razie - jak wyraził się Mikołaj Bierdiajew - powoduje ona wyjałowienie życia ludzkiego i staje się narzędziem interesowności oraz ucisku).

Współczesne środki komunikacji w pełni objawiły swoje możliwości ludziom cywilizacji zachodniej, choć i bez nich dzisiejszy człowiek niemalże przekracza granice swojego istnienia, a za pośrednictwem telewizji ma możliwość jednoczesnego przebywania we wszystkich miejscach planety. Jednakże, mimo gwałtownego tempa Postępu technocentrycznego, oceanu płytkich informacji i widowisk wątpliwej jakości, dusza ludzka nie rośnie, lecz karłowacieje, a życie duchowe podupada. Również nasza kultura, mimo, iż próbuje odwrócić uwagę od swego fatalnego stanu banalnymi nowościami, ubożeje i blaknie. Coraz bardziej wzrasta poczucie komfortu, podczas gdy poziom rozwoju duchowego ulega obniżeniu. Następuje przesycenie i ogarnia nas dławiący smutek, że w wirze przyjemności nie znajdujemy uspokojenia, że takie życie nie potrwa długo.

Nie pokładajmy całej nadziei w nauce, technologii, wzroście ekonomicznym. Zwycięska cywilizacja zaszczepiła w nas duchową niepewność. Prezenty, które nam ofiarowuje, są nie tylko dobrodziejstwem, ale i zniewoleniem. Interesy stanowią o wszystkim, nie można ich zaniedbać. Trwa ciągła walka o dobra materialne, a tymczasem serce podpowiada, że stracono coś czystego, wzniosłego i delikatnego. Przestaliśmy widzieć c e l.

Przyznajmy więc, choćby szeptem i sami przed sobą: w i mię c ze go żyjemy w tym szaleńczym tempie?

\section{Nie można uciec przed odwiecznymi problemami}

Postęp w żaden sposób nie może ulec zatrzymaniu, jednakże jest od nas zależny. Przestańmy więc traktować go jako źródło nieograniczonych dóbr, a zacznijmy odbierać jako dar, który jest bardzo skomplikowaną próbą naszej woli.

Na przykład dar telefonu i telewizji, używany bez umiaru, zaburzył ludzkie poczucie czasu, naturalny bieg życia, niejako wytrącił człowieka 
z odwiecznego rytmu życia. Z kolei dar wydłużonego życia ludzkiego sprawił, że ludzie starsi są ciężarem dla ludzi w średnim wieku. Starcy skazani są na długą samotność, opuszczenie przez bliskich oraz pozbawienie radości przekazania duchowego doświadczenia najmłodszym.

Poziome więzi duchowe między ludźmi ulegają zerwaniu. Pomimo, iż życie polityczne i społeczne wydaje się wrzeć, wzrasta tendencja do wzajemnego izolowania się od siebie, wyobcowania oraz braku współodczuwania między ludźmi, którzy zajęci są sprawami materialnymi. Efektem jest bolesna samotność. (Właśnie to zjawisko stało się przyczyną powstania egzystencjalizmu.)

Nie powinniśmy tak łatwo poddawać się mechanizmowi Postępu, lecz musimy próbować duchowo go przeobrazić, z korzyścią dla nas. Trzeba szukać takich sposobów wprowadzenia zmian (albo doskonalić rozwiązania już znane), które sprawią, że nie będziemy marionetkami Postępu, lecz wykorzystamy jego siłę dla czynienia rzeczywistego dobra.

Postęp, rozumiany jako niosący radość i biegnący po linii prostej wektor, okazał się wielokrotną krzywą, która spowodowała powrót do odwiecznych problemów stojących przed ludzkością. Oswojenie się z nimi naszym przodkom poszło z pewnością łatwiej, gdyż nie byli tak roztargnieni i chaotyczni jak my.

Straciliśmy naturalną harmonię wewnętrzną, z której jesteśmy stworzeni - harmonię między sferą duchową a fizyczną. Zagubiliśmy też wewnętrzne rozeznanie czym jest Dobro i Zło. Obecnie pojęcia te uległy spłyceniu i - według zasady fifty-fifty - zostały skażone bzdurami.

Nic tak nie pokazuje naszej obecnej bezradności duchowej i niepokoju intelektualnego jak utrata jasnego, spokojnego stosunku do śmierci. Im bardziej wzrasta dobrobyt ludzki, tym silniej wkrada się w duszę współczesnego człowieka paraliżujący, nieznany w dawnych czasach, strach przed śmiercią. Nienasycone, hałaśliwe oraz niespokojne życie sprawiło, iż przybrał on charakter masowy. Człowiek przestał odczuwać siebie jako ograniczony - chociaż obdarzony wolą - punkt we Wszechświecie, a w coraz większym stopniu zaczął uważać się za centrum otaczającej go rzeczywistości, nie siebie dostosowując do świata, lecz świat do siebie. W takim wypadku myśl o własnej śmierci staje się nie do zniesienia, gdyż oznacza ona jednoczesny koniec całego Wszechświata.

Wypierając ze swojej pamięci Siłę Wyższą, wprowadziliśmy w życie prywatne imperatywy i nagle stało się ono nie do zniesienia. 


\section{Po zimnej wojnie}

Druga połowa XX wieku upłynęła pod znakiem zagrożenia nuklearnego, którego bezwzględność przeszła wszelkie granice wyobraźni. Fakt ten przesłonił inne negatywne strony życia ludzkiego. Wszystko wydawało się nieważne - i tak zginiemy, więc żyj jak chcesz. Wielkie Zagrożenie miało także wpływ na zatrzymanie rozwoju ducha ludzkiego i rozważań nad sensem życia.

Paradoksalnie jednak, to niebezpieczeństwo na długo nadało społeczeństwu zachodniemu pewien jednoczący sens istnienia - trzeba się wzmocnić i wytrwać wobec śmiertelnego zagrożenia ze strony komunizmu. Rzecz jasna nie wszyscy do końca zdawali sobie sprawę z zagrożenia. Problem ten nie dotykał każdego w jednakowym stopniu. Pojawiło się sporo malkontentów podważających zachodnie stanowisko, lecz przewaga odpowiedzialnych ludzi w rządach uratowała Zachód i pozwoliła wygrać mu walkę o Berlin, Koreę, a także uchronić od zagłady Grecję i Portugalię. (Był taki czas, kiedy wodzowie komunizmu mogli dokonać błyskawicznego ataku, nie doczekawszy się w zamian nuklearnej odpowiedzi. Chyba tylko hedonizm tych zgrzybiałych przywódców sprawił, że ciągle odkładali ten zamysł. Potem zaś prezydent Reagan - rozpętawszy spiralę zbrojeń, której komuniści nie byli w stanie podołać - zostawił ich daleko w tyle).

W końcu XX wieku pojawił się, oczekiwany przez wielu moich rodaków, lecz zupełnie nieoczekiwany na Zachodzie, fenomen. Z powodu odwiecznej martwoty i od dawna gromadzącej się zgnilizny, komunizm sam się rozleciał. Upadek nastąpił nagle i jednocześnie w wielu krajach. Natychmiast zniknęło też zagrożenie atakiem atomowym.

I cóż? Nad światem przemknęły krótkie miesiące radosnej ulgi (dla niektórych był to czas lamentu nad śmiercią ziemskiej Utopii, socjalistycznego raju na Ziemi). Przemknęły, ale na planecie nie zrobiło się spokojniej. Nawet jakby częściej - to tu, to tam - rozlegały się wybuchy, eksplozje, wystrzały. Wojska ONZ przestały wystarczać dla zabezpieczenia pokoju.

Na terytorium byłego ZSRR komunizm jeszcze się nie skończył. W niektórych republikach zachowały się jego pełne i realne formy, a we wszystkich - milionowe kadry komunistów i nieśmiertelne pierwiastki w świadomości i bycie. Jednocześnie, w czasie narodowej szarpaniny, pojawiły się nowe piekące wrzody. Na przykład: już na początku krwiożerczego kapitalizmu, mieliśmy do czynienia z grabieżą mienia narodowego i tak wstrętnymi przykładami zachowań, że nawet Zachód nie był świadkiem podobnych wydarzeń. W efekcie, wśród nieprzygotowanej i bezbronnej ludności pojawiła się tęsknota za dawną „równością w ubóstwie”. 
Mimo upadku ziemskiego ideału socjalizmu-komunizmu, wciąż aktualne pozostały kwestie, na które miał on jakoby odpowiadać: niegodziwość w wykorzystaniu przywilejów społecznych i nadmierna siła pieniądza, często kierująca całym biegiem wydarzeń. Jeśli ogólnoświatowa lekcja XX wieku nie spełni funkcji szczepienia ochronnego, to cała ta czerwona zaraza może się powtórzyć.

Zimna wojna dobiegła końca, lecz problemy współczesnego życia okazały się o wiele bardziej złożone niż wtedy, gdy mieściły się w dwóch wymiarach politycznych. Jeszcze dobitniej objawił się nam wcześniejszy kryzys egzystencjalny. Problem pustki duchowej - zaniedbany w ciągu dziesięcioleci zagrożenia atomowego - znacząco się pogłębił. W epoce równowagi spowodowanej zagrożeniem atomowym istniała tylko iluzja - możliwej na krótko stabilności istnienia. Teraz zaś znów pojawia się przed nami to samo trudne pytanie: dokąd zmierzamy?

\section{Na przełomie wieków}

Symbolicznie zbliżamy się do przełomu wieków, a nawet Tysiącleci. Niecałe osiem lat dzieli nas od tej historycznej granicy. (Charakterystyczna dla naszych czasów gorączkowość sprawia, iż Nowy Wiek jest ogłaszany o rok wcześniej. Nikt nie czeka roku dwa tysiące pierwszego).

Któż z nas nie chciałby powitać tego uroczystego przełomu w uniesieniu i pełen nadziei? Wielu tak właśnie witało wiek dwudziesty - jako czas wyższości rozumu - i nie wyobrażało sobie, jakie nieszczęścia czekają człowieka w tym okresie. Wydaje się, że jeden tylko Dostojewski przewidział nadciągający totalitaryzm.

W XX wieku moralność ludzka nie wzrosła. Wręcz przeciwnie: o wiele częściej dochodziło do zniszczeń. Kultura gwałtownie podupadła, a życie duchowe zubożało (chociaż - co zrozumiałe - swój udział miał w tym także wiek dziewiętnasty). Czy możemy zatem oczekiwać, że w XXI wieku - kiedy pojawiły się rozmaite rodzaje broni śmiercionośnej - sytuacja się poprawi?

Do tego dochodzi jeszcze degradacja przyrody, szybki wzrost liczby mieszkańców Ziemi oraz problem Trzeciego Świata, wciąż jeszcze nazywanego w ten uogólniający i nieadekwatny sposób. W jego skład wchodzi przecież cztery piąte ludzkości. Wkrótce żyć będzie tam pięć szóstych ludności świata i tym sposobem stanie się on jednym z ważniejszych podmiotów dwudziestego pierwszego stulecia, który tonąc w nieszczęściach i ubóstwie, niewątpliwie wysunie swoje roszczenia wobec państw wysokorozwiniętych. (Podobne pomysły pojawiały się już u zarania komunizmu radzieckiego. Mało kto wie, że w 1921 roku komunista i nacjonalista tatarski Sułtan Galijew 
proponował utworzyć Międzynarodówkę Państw Kolonialnych i Półkolonialnych oraz ustanowić jej dyktaturę nad krajami rozwiniętymi). Dzisiejszy Zachód czuje się tak, jakby znajdował się w twierdzy - chociażby ze względu na rosnący napór uchodźców, którzy wdzierają się przez wszystkie granice europejskie. Mieszkańcy wspomnianej twierdzy są na razie dość szczęśliwi, lecz wiedzą, że znajdują się pod oblężeniem. Jednakże w przyszłości, na skutek narastającego kryzysu ekologicznego mogą zmienić się strefy klimatyczne. W miejscach, gdzie wcześniej pod dostatkiem było słodkiej wody i żyznej gleby, nagle jej zabraknie. Może to wywołać nowe groźne konflikty, doprowadzić do wojny o przetrwanie.

Zachód stoi przed trudnym zadaniem utrzymania równowagi $\mathrm{w}$ ten sposób, by zachowując pełen szacunek dla pluralizmu kultur światowych i ich własnych poszukiwań rozwiązań socjalnych, nie zgubić swojego - osiąganego tak długo i z trudem - unikatowego pod względem historycznym status quo, chronionego regułami życia oraz dającego niezależność i swobodę każdemu obywatelowi.

\section{Samoograniczenie}

Zbliża się ostateczny termin ograniczenia własnych potrzeb. Czy trudno zdecydować się na poświęcenie i przyjęcie niewygodnych zasad? Trudno, gdyż zarówno w życiu osobistym, społecznym, jak i państwowym dawno już wyrzuciliśmy na dno morza złoty klucz Samoograniczenia. A przecież samoograniczenie jest najważniejsze i najrozsądniejsze dla człowieka, który otrzymał wolność. To najwłaściwsza droga realizowania wolności. Dlatego nie możemy czekać, aż wydarzenia nas przytłoczą i przerosną nasze możliwości. Przezornie stosując samoograniczenie będziemy zdolni pogodzić się $\mathrm{z}$ nieuchronnym biegiem wydarzeń.

O tym, iż w życiu osobistym zbaczamy z obranej drogi, wie tylko nasze sumienie oraz nasi bliscy. Natomiast podobne postępowanie dużych podmiotów - partii lub państw - widzą wszyscy.

Wobec bliskiego zagrożenia atmosfery i środowiska naturalnego, zwołuje się konferencję zaniepokojonych narodów świata. Tymczasem potężne mocarstwo - posiadające prawie połowę wykorzystywanych obecnie zasobów naturalnych i wytwarzające połowę zanieczyszczenia światowego - mając na uwadze swoje aktualne interesy wewnętrzne, żąda obniżenia wymagań tego rozważnego porozumienia międzynarodowego. Zupełnie tak, jakby nie było zmuszone żyć na tej samej Ziemi. Z kolei inne państwa rozwinięte uchylają się od wypełnienia już obniżonych wymagań. W ten oto sposób biorąc udział w wyścigu ekonomicznym - zatruwamy sami siebie. 
Także podczas rozpadu ZSRR, który odbył się przy wykorzystaniu fałszywych granic stworzonych przez system leninowski, mieliśmy do czynienia z porażającymi przejawami mocarstwowości. Nowe państwa powstały w rozległych - odmiennych historycznie i etnicznie - regionach, gdzie żyją dziesiątki tysięcy, a nawet miliony obcej ludności. Postąpiły bardzo krótkowzrocznie nie zastanawiając się nad wnioskami, jakie nasuwa historia. Żadne zagarnięcie obcego terytorium nigdy nie wyszło na dobre zaborcy.

Przenosząc zasadę samoograniczenia na społeczności ludzkie, na zawody, partie polityczne i państwa, rodzi się więcej trudnych pytań, niż ktokolwiek może znaleźć odpowiedzi. Wszelkie decyzje o poświęceniach i ograniczeniach odbiją się na wielu ludziach - być może nieprzygotowanych na to i wyrażających sprzeciw. (Przecież nawet ograniczenie zakupu towarów, dokonywane przez konsumentów indywidualnych, odbije się niepostrzeżenie na producentach.)

Jeśli nie nauczymy się sami ustalać sztywnych granic dla naszych pragnień i żądań oraz podporządkowywać interesy kryteriom moralnym, to jako ludzkość - zostaniemy po prostu rozszarpani. Swoje kły szczerzą na nas najgorsze strony natury ludzkiej.

Różni myśliciele nie raz mówili - niemalże dosłownie posługując się opinią dwudziestowiecznego filozofa rosyjskiego Mikołaja Łosskiego - że jeśli ludzie nie zrezygnują z prymatu jednostki, to w ich życie nieuchronnie wkradnie się rozkład i zepsucie. Z moich obserwacji wynika, iż prawdziwą satysfakcję duchową odczuwamy nie wtedy gdy zyskujemy jakieś dobro, lecz wtedy, gdy z niego zrezygnujemy. Gdy poddamy się samoograniczeniu.

Dziś samoograniczenie wydaje się nam nie do przyjęcia, jawi się jako krępujące, a nawet wstrętne. W ciągu wieków odwykliśmy od tego, do czego zmuszeni byli przywyknąć nasi przodkowie - spoczywało na nich o wiele więcej ograniczeń zewnętrznych, o ileż mniej zaś mieli przed sobą możliwości. Wyjątkowa ważność samoograniczenia - z punktu widzenia ludzkości - dała o sobie znać dopiero w wieku XX. Lecz nawet przy różnorodności wzajemnych związków, które przenikają dzisiejszą egzystencję, tylko dzięki niemu możemy - stopniowo i z wielkim uporem - poprawić nasz status ekonomiczny i polityczny.

Niewielu z chęcią postąpi według tej zasady. Jednakże - ze względu na złożoność naszej rzeczywistości - samoograniczenie to jedyna pewna droga ratunku. Pomoże ona przywrócić świadomość istnienia Jedynego i Najwyższego oraz wzbudzi wobec Niego całkowicie utracone przez nas uczucie pokorę.

Postęp? Może on być tylko sumą postępów duchowych każdego indywiduum, będących wynikiem ich samodoskonalenia się. 
Niedawno rozbawiano nas naiwną bajką o mającym nastąpić, szczęśliwym „końcu historii”, triumfie demokracji. Miał on być ostatecznie najbardziej rozpowszechnionym w świecie typem ustroju.

Tymczasem, zauważamy, że następuje coś całkiem innego, najprawdopodobniej znów niebezpiecznego. Pokój na naszej planecie nie zapanuje szybko i nie osiągniemy go tak łatwo.

Jednakże, nie na darmo doświadczyliśmy wydarzeń wieku XX. Miejmy nadzieję, że - podobnie jak nasi przodkowie - wytrwamy i tę wytrwałość w jakiś sposób przekażemy przyszłym pokoleniom.

P R Z E Ł O Z Y ŁUKA S Z G E M Z I A K

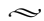

ŁUKASZ GEMZIAK

Instytut Filologii Słowiańskiej UMK

\title{
Samoograniczenie - koncepcja wolnosci Aleksandra Sołżenicyna
}

\begin{abstract}
A leksander Isajewicz Sołżenicyn (1918-2008) - znany pisarz-beletrysta, Alaureat literackiej Nagrody Nobla (1970), zdobył światowy rozgłos głównie za sprawą swojej działalności prozatorskiej. Także w Polsce zasłynął on ze względu na swe dokonania artystyczne. Jednakże ten rosyjski prozaik (pisał również utwory dramatyczne) był również publicystą, myślicielem politycznym, historiozofem oraz moralistą. Osiągnięcia Sołżenicyna na tym polu są o wiele mniej znane i część jego poglądów nie została jeszcze w sposób wyczerpujący przedstawiona polskiemu czytelnikowi. Warto więc zwrócić uwagę na jedno z pojęć, jakim często posługiwał się noblista, stanowiące asumpt do rozważań nad wolnością i przyszłością ludzi oraz narodów. Samoograniczenie - gdyż o nim mowa - odgrywa rolę czynnika mającego poprawić kondycję moralną ludzkości. Stosowane zarówno wobec jednostki, jak i dużych podmiotów politycznych może być - według rosyjskiego noblisty - remedium na kryzys, który dotknął wiele sfer życia ludzkiego.
\end{abstract}

\section{Skrucha i samoograniczenie}

W listopadzie 1973 roku Sołżenicyn napisał esej Skrucha i samoograniczenie jako kategorie życia narodowego, który - mimo upływu wielu lat - uważany był przez samego autora za jedno z jego najważniejszych dokonań, wy- 